\title{
PENINGKATKAN KEMAMPUAN BERCERITA DENGAN MENGGUNAKAN MEDIA FILM ANIMASI SISWA
}

\author{
Selvi Meila Puspita ${ }^{1)}$, Ani Diana ${ }^{2)}$ \\ ${ }^{12}$ FKIP Universitas Muhammadiyah Pringsewu Lampung \\ Pos-el: selvidungin@gmail.com, anidiana@umpri.ac.id.
}

\begin{abstract}
Abstrak
Keterampilan berbicara merupakan salah satu keterampilan utama yang wajib diajarkan pada semua jenjang pendidikan. Adapun ruang lingkup keterampilan berbicara yang diajarkan di sekolah terutama di tingkat sekolah Dasar salah satunya adalah bercerita. Pembelajaran bercerita khususnya pada indikator menceritakan kembali cerita yang didengar dengan kata-kata sendiri merupakan salah satu materi yang dianggap sulit oleh siswa sehingga banyak siswa yang kemampuannya belum memadai dalam bercerita. Untuk itu perlu dilakukan penelitian dengan tujuan agar kemampuan bercerita siswa dapat meningkat. Dalam melaksanakan penelitian ini peneliti berkolaborasi dengan guru kelas. Dari hasil analisis data dapat diketahui bahwa terdapat peningkatan kemampuan bercerita siswa dengan menggunakan media film animasi. Hal ini dapat terlihat pada pelaksanaan siklus I kemampuan siswa meningkat menjadi 57,044 dibanding dengan sebelum menggunakan media film animasi hanya 49,27. Selanjutnya pada siklus II lebih meningkat dari siklus I yakni sebesar 75,34.
\end{abstract}

Kata Kunci: PTK, Bercerita, Media Film Animasi.

\begin{abstract}
Speaking skill is one of the main skills that must be taught at all levels of education. The scope of speaking skills taught in schools, especially at the elementary school level, one of which is storytelling. Learning to tell stories, especially on indicators of retelling stories heard in their own words, is one of the materials considered difficult by students so that many students have insufficient ability to tell stories. For this reason, it is necessary to conduct research with the aim that students' storytelling abilities can be increased. In carrying out this research, the researcher collaborated with the classroom teacher. From the results of data analysis, it can be seen that there is an increase in students' storytelling skills using animated film media. This can be seen in the implementation of the first cycle, the students' ability increased to 57,044 compared to before using the animated film media, which was only 49.27. Furthermore, in the second cycle, it increased more than the first cycle, which was 75.34.
\end{abstract}

Keywords: PTK, Storytelling, Animation Film Media 


\section{PENDAHULUAN}

Keterampilan berbicara sangat penting untuk dikuasai oleh siswa. Hal ini mengingat sebagian besar aktivitas dalam berkomunikasi sehari-hari lebih banyak dilakukan secara melalui berbicara (lisan). Secara konvensional komunikasi secara lisan selama ini banyak dilakukan dengan menggunakan tatap muka langsung (face to face). Namun, untuk saat ini di mana teknologi sudah semakin canggih komunikasi lisan tidak hanya dapat dilakukan secara face to face tetapi juga dengan menggunakan berbagai media elektronik seperti telepon, telepon genggam, whatsapp, telegram, twitter, instagram, dan lain-lain. Dengan bantuan media elektronik tentunya akan mempermudah dan mempercepat komunikasi yang dilakukan. Penggunaan media elektronik ini juga akan sangat bermanfaat untuk membantu kemampuan berkomunikasi atau berbicara siswa, yakni dengan cara melibatkan media elektronik dalam pembelajarannya.

Keterampilan berbicara merupakan kegiatan mengucapkan bunyibunyi artikulasi atau kata-kata untuk mengekspresikan, mengatakan serta menyampaikan pikiran, gagasan, dan perasaan (Arsjad dan Mukti, 1991: 17). Keterampilan berbicara berkaitan erat dengan keterampilan berbahasa lainnya karena kemampuan berbicara membutuhkan keterampilan mendengar dan membaca. Sebagian besar materi atau bahan yang digunakan di dalam berbicara didapat dari mendengar dan membaca.

Tujuan utama dari berbicara adalah untuk berkomunikasi. Untuk itu, keterampilan berbicara sering juga disebut dengan kemampuan berkomunikasi. Dalam berbicara atau berkomunikasi seorang pembicara dituntut untuk menguasai aspek-aspek yang menentukan dalam kefektifan berbicara, seperti ketepatan dalam pelafalan, penggunaan struktur kalimat, penggunaan kosakata, dan penguasaan masalah atau topik pembicaraan. Aspek-aspek tersebut perlu dikuasai agar pesan atau informasi yang disampaikan dapat diterima dengan mudah oleh lawan berbicara sesuai dengan yang dimaksudkan oleh si pembicara.

Keterampilan berbicara merupakan salah satu keterampilan utama yang wajib diajarkan pada semua jenjang pendidikan, dari taman kanak-kanak sampai jenjang perguruan tinggi. Adapun ruang lingkup keterampilan berbicara yang diajarkan di sekolah, terutama di tingkat sekolah dasar salah satunya adalah bercerita. Keterampilan bercerita sangat 
penting diajarkan kepada anak-anak sejak sekolah dasar bahkan sejak taman kanakkanak karena melalui bercerita anak dilatih untuk mengembangkan kemampuan berpikir, kesiapan mental, dan keberaniannya. Di samping itu, dengan melatih keterampilan bercerita siswa, berarti melatih pula kemampuan berbicaranya secara teratur dan sistematis. Kompetensi yang diharapkan setelah siswa mempelajari aspek berbicara di Sekolah Dasar yaitu siswa mampu berbicara dengan tepat dan lancar. Adapun indikator atau pedoman dalam menentukan kemampuan berbicara atau bercerita menurut Arsjad dan Mukti (1991: 17-22) di antaranya: (1) pelafalan, (2) intonasi (penempatan tekanan, nada, sendi dan durasi) yang sesuai, (3) penggunaan kata, (4) penggunaan kalimat, (5) sikap yang wajar dan tenang, (6) pandangan mata, (7) sikap tubuh dan mimik muka, (8) kelantangan suara, (9) keruntutan, (10) penguasaan topik.

$$
\text { Pembelajaran keterampilan }
$$

berbicara terutama bercerita juga telah diajarkan di kelas V SD Negeri 1 Wonosobo Kabupaten Tanggamus sesuai dengan kurikulum yang berlaku dengan kompetensi dasar "mengidentifikasi unsur cerita rakyat yang didengarnya", dengan indikator "menceritakan kembali cerita yang didengar dengan kata-kata sendiri”. Namun, dari informasi yang peneliti peroleh dari hasil prapenelitian diketahui masih banyak siswa yang kurang mampu berbicara atau bercerita. Kekurangmampuan siswa dalam bercerita ini salah satunya disebabkan pembelajaran kurang menarik sehingga siswa lebih banyak pasif saat pembelajaran sedang berlangsung, dan lebih banyak gurunya yang aktif. Guru lebih banyak memberikan ceramah atau menjelaskan teori berbicara tanpa menggunakan media relevan untuk pembelajaran berbicara. Oleh karena itu, untuk meningkatkan aktivitas dan kreativitas siswa tersebut maka perlu digunakan media pembelajaran yang tepat dan menarik. Media pembelajaran merupakan segala sesuatu yang dapat digunakan untuk menyalurkan pesan dan merangsang terjadinya proses belajar pada siswa (Aqib, 2013: 50). Pengertian media pembelajaran lebih luas dari alat peraga, alat bantu mengajar, media audio visual. Media belajar juga merupakan kombinasi antara alat (hardware) dan bahan (software). Dengan adanya media pembelajaran materi yang disampaikan akan lebih mudah dipahami oleh siswa sehingga pembelajaran lebih efektif, efisien, dan menyenangkan. Adapun 
tujuan penggunaan media pembelajaran untuk: (1) menyeragamkan penyampaian materi, (2) pembelajaran lebih jelas dan menarik, (3) proses pembelajaran lebih interaksi, (4) efisiensi waktu dan tenaga, (5) meningkatkan kualitas hasil belajar, (6) belajar dapat dilakukan kapan saja dan dimana saja, (7) menumbuhkan sikap positif belajar terhadap proses dan materi belajar, (8) meningkatkan peran guru ke arah yang lebih positif dan produktif (Aqib, 2013: 51).

Penggunaan media dalam pembelajaran berbicara sangat penting untuk meningkatkan kualitas pembelajaran berbahasa karena dengan adanya media siswa dapat lebih aktif dan termotivasi untuk berbicara. Hal ini sebagaimana yang disampaikan oleh Munadi (2013: 7-8) bahwa media pembelajaran merupakan sarana penting untuk menyampaikan pesan kepada penerimanya sehingga tercipta lingkungan belajar yang kondusif. Di samping itu penggunaan media yang tepat akan meningkatkan efektivitas dan efisiensi dalam pembelajaran.

Salah media pembelajaran yang dapat digunakan dalam pembelajaran berbicara atau bercerita adalah film animasi. Film animasi merupakan salah satu media audio visual yang berisi rangkaian gambar tak hidup tetapi diproyeksikan dengan menggunakan peralatan elektronis untuk ditampakkan pada layar menjadi hidup untuk ditampakkan pada layar. Penggunaan media film animasi dapat menjembatani pembelajaran lebih menarik dan menyenangkan. Film animasi merupakan sebuah media yang menggabungkan antara audio dan visual dengan cerita lucu yang sering pula disebut dengan kartun. Kartun merupakan gambar lucu yang berisi humor. Animasi merupakan kumpulan gambar dari sebuah objek yang diolah menghasilkan gerakan tertentu sehingga gambar tersebut seolah-olah hidup.

Menurut Danim (2010: 19) film memiliki nilai untuk melengkapi pengalaman-pengalaman yang ada, merangsang munculnya ide baru, memberikan rekreasi dan nilai-nilai positif dalam pembelajaran. Di samping itu, media film animasi juga dapat mempermudah guru dalam menyampaikan materi pembelajaran karena materi lebih mudah diingat dan dipahami oleh siswa.

\section{METODE PENELITIAN}

Penelitian ini dilakukan melalui penelitian tindakan kelas (PTK). Penelitian tindakan kelas (PTK) 
merupakan penelitian tindakan untuk memperbaiki mutu atau kualitas pembelajaran di kelas (Suhardjono, 2010: 12). Di dalam penelitian tindakan kelas ada tindakan nyata yang diyakini lebih baik dari yang biasa dilakukan. Selanjutnya Kusnandar (2011: 44-45) mendefinisikan penelitian tindakan kelas adalah sebagai suatu penelitian yang dilakukan oleh guru yang sekaligus sebagai peneliti di kelasnya atau bersamasama dengan orang lain (kolaborasi) dengan tahapan melalui perencanaan, pelaksanaan, serta melakukan refleksi untuk memperbaiki atau meningkatkan kualitas proses pembelajaran di kelas melalui suatu siklus. Tujuan utama PTK adalah untuk memecahkan permasalahan nyata yang terjadi di kelas dan meningkatkan kegiatan nyata guru dalam kegiatan pengembangan profesinya. Pelaksanaan penelitian tindakan kelas meliputi: perencanaan (planning), pelaksanaan (acting), pengamatan tindakan (pengumpulan data dan informasi), refleksi (reflecting), yang meliputi: data yang didapat dianalisis, dalam analisis dapat melibatkan orang luar, dan menarik kesimpulan.

Pelaksanakan tindakan dilakukan dengan dua siklus, yaitu siklus I dan siklus II. Pada siklus I pembelajaran dilaksanakan dengan menggunakan media animasi yang berisi cerita untuk anakanak dalam bentuk tayangan melalui laptop dan diproyeksikan melalui LCD. Setelah ditayangkan maka siswa diberi kesempatan untuk melakukan tanya jawab tentang isi film tersebut. Setelah itu siswa diminta untuk menceritakan kembali secara lisan. Hal ini juga berlaku untuk siklus yang ke II.

Adapun subjek dalam penelitian ini adalah siswa kelas $\mathrm{V}$ B yang berujumlah 22 siswa. Peneliti menentukan siswa kelas V B sebagai subjek penelitian karena kemampuan siswa di kelas ini lebih rendah dibandingkan dengan kelas V A. Di samping itu dalam kemampuan berbicarapun siswa kelas $\mathrm{V}$ banyak yang belum mampu berbicara dengan baik, terutama penggunaan kalimat dan intonasi.

\section{HASIL DAN PEMBAHASAN}

Hasil penelitian yang diperoleh berupa nilai kemampuan siswa dalam berbicara, khususnya bercerita. Hasil tes pada prasiklus, siklus I, dan siklus II dapat dilihat pada tabel berikut: 
Tabel 1

Nilai Kemampuan Bercerita Siswa

\begin{tabular}{|c|c|c|c|c|}
\hline \multirow{3}{*}{ No. } & \multirow{3}{*}{ Nama } & \multicolumn{3}{|c|}{ Penilaian } \\
\hline & & \multirow{2}{*}{ Prasiklus } & \multicolumn{2}{|c|}{ Siklus } \\
\hline & & & I & II \\
\hline 1 & $\begin{array}{l}\text { Ahmad Alan } \\
\text { Raihan }\end{array}$ & 45 & 50 & 75 \\
\hline 2 & Aliya Tri Habsari & 55 & 56,25 & 75 \\
\hline 3 & $\begin{array}{l}\text { Anggelia } \\
\text { Suprobo }\end{array}$ & 45 & 61,25 & 75 \\
\hline 4 & Arifatul Kayana & 56 & 58,75 & 87,5 \\
\hline 5 & $\begin{array}{l}\text { Arjuna Setia } \\
\text { Wijaya }\end{array}$ & 55 & 56,25 & 75 \\
\hline 6 & $\begin{array}{l}\text { Bagus Nevan } \\
\text { Widodo }\end{array}$ & 70 & 81,25 & 91,25 \\
\hline 7 & Damar Anggara & 40 & 50 & 70 \\
\hline 8 & Firmansyah & 35 & 50 & 71,25 \\
\hline 9 & $\begin{array}{l}\text { Irena Chyntya } \\
\text { Dewi }\end{array}$ & 68 & 68,75 & 89,95 \\
\hline 10 & Kafi Narendra & 67 & 75 & 85 \\
\hline 11 & Kiki Aprilia & 54 & 56,25 & 75 \\
\hline 12 & M. Al Farizi & 50 & 56,25 & 75 \\
\hline 13 & M. Fariz Ahnaf & 72 & 81,25 & 95 \\
\hline 14 & M Naufal D H & 35 & 50 & 71,25 \\
\hline 15 & Muhjir Khairul A & 30 & 43,75 & 70 \\
\hline 16 & Rachel Putri & 35 & 43,75 & 56,25 \\
\hline 17 & Satria Hamzahya & 48 & 61,25 & 71,25 \\
\hline 18 & Selfia Yunar S & 64 & 65 & 81,25 \\
\hline 19 & Sulthon Zahran & 40 & 43,75 & 68,75 \\
\hline 20 & Talisa Febri & 52 & 53,75 & 71,25 \\
\hline 21 & Tommy Heryanto & 42 & 46,25 & 68,75 \\
\hline 22 & $\begin{array}{l}\text { Zulvikar Joyo } \\
\text { Wijoyo }\end{array}$ & 35 & 46,25 & 58,75 \\
\hline \multicolumn{2}{|c|}{ Rata-rata } & 49,27 & 57,04 & 75,34 \\
\hline
\end{tabular}

Tabel di atas menunjukkan bahwa hasil prasiklus sebelum menggunakan media film animasi, kemampuan siswa dalam menceritakan kembali cerita yang didengar dengan kata-kata sendiri mencapai nilai rata-rata 49,27. Siswa yang tuntas ada 3 (14\%), dan belum tuntas 19 (86\%). Banyaknya siswa yang tidak mencapai ketuntasan dan nilai ratarata yang belum mencapai KKM mata pelajaran bahasa Indonesia di SD Negeri 1 Wonosobo, merupakan masalah yang perlu diselesaikan dan perlu upaya peningkatan. Pada siklus I, setelah pembelajaran menggunakan film animasi diperoleh rata-rata kemampuan siswa mencapai 57,04, lebih tinggi daripada sebelumnya. Jumlah siswa yang tuntas ada (18\%) dan yang belum tuntas 18 $82 \%)$. Siswa yang mencapai ketuntasan pada siklus I lebih banyak daripada saat prasiklus. Selanjutnya pada siklus II diperoleh nilai rata-rata siswa sebesar 75,34. Siswa yang sudah tuntas ada 20 (91\%) dan yang belum tuntas $2(9,0 \%)$. Terjadinya peningkatan nilai siswa dari prasiklus ke siklus I dan II menunjukkan bahwa penggunaan media film animasi efektif untuk digunakan dalam pembelajaran berbicara (bercerita). Nilai prasiklus dengan nilai rata-rata 49,27 mengalami peningkatan pada siklus I menjadi 57,04 kemudian terjadi peningkatan kembali pada siklus II yaitu dengan nilai rata-rata sebesar 75,34.

\section{SIMPULAN}

Dari analisis data dan pembahasan yang penelitikan telah lakukan dapat disimpulkan bahwa penggunaan film animasi dalam pembelajaran dapat meningkatkan kemampuan siswa dalam berbicara (bercerita). Hal ini terbukti dengan adanya 
Selvi Meila Puspita, Ani Diana...

peningkatan rata-rata kemampuan siswa dari prasiklus ke siklus I dan II, yakni dari 49,27 menjadi 57,04 dan 75,34.

\section{DAFTAR PUSTAKA}

Aqib, Zainal. (2013). Model-model, Media, dan Strategi Pembelajaran Kontekstual. Bandung: CV Yrama Widya.

Arsjad, Maidar G. dan Mukti. (1991). Pembinaan Kemampuan Berbicara Bahasa Indonesia. Jakarta: PT Gelora Aksara Pratama.

Kusnandar. (2011). Penelitian Tindakan Kelas. Jakarta: PT Rajawali Pers.

Suhardjono. (2010). Penelitian Tindakan Kelas \& Tindakan Sekolah. Malang: Cakrawala Indonesia Bekerjasama dengan LP3 UM.

Yudhi Munadi. (2013). Media Pembelajaran Sebuah Pendekatan Baru. Jakarta:GP Press Group. 